\title{
A Tragedy of Existence: An Existential Analysis of Giles Winterborne in The Woodlanders
}

\author{
Yanjuan Chen \\ College of Foreign Languages, Chongqing University, Chongqing, China \\ Email: lovecyj628@163.com
}

\begin{abstract}
This paper is an existential analysis of Giles Winterborne, the protagonist of Thomas Hardy's novel The Woodlanders. On the basis of existentialism, this paper explores the absurdity of the world in which Winterborne is living, his alienation and bad faith. These three elements combine to cause his tragic death. Thus, this novel reveals Hardy's anxiety over the moral and spiritual crisis at the turn of the $20^{\text {th }}$ century and his concerns over human existence.
\end{abstract}

Index Terms - existentialism, absurdity, alienation, bad faith

\section{INTRODUCTION}

Thomas Hardy is not only a prominent novelist and poet, but also a keen thinker at the turn of the $20^{\text {th }}$ century, an age full of great social changes and ideological contradictions. Witnessing so many changes and contradictions, Hardy explores the awkward living conditions of people at his time and his many works are full of serious philosophical thinking of human existence. His novel The Woodlanders (1887) is a reflection of his thinking. In the novel, the protagonist, Giles Winterborne is in face of the predicament of existence. He feels alienated, experiences anxiety and is pushed into the helpless and despair situation. Winterborne is an embodiment of the people living at the turn of the $20^{\text {th }}$ century and his predicament indicates the embarrassing living conditions of that time.

This paper carries on an existential analysis of Giles Winterborne on the basis of the philosophy of existentialism and explores the absurdity of the world, Winterborne's alienation and his bad faith. This research has provided a new way to understand The Woodlanders and Thomas Hardy.

\section{ABSURDITY OF THE LITTLE HINTOCK}

For the existentialists, human beings, like seeds, are cast into this world occasionally. The occasionality makes it difficult for men to get command of the reality and they feel uncertain in confrontation with the contingencies of the vast world. The world runs counter to man's dreams and makes it difficult or impossible for him to realize his dreams. Sartre holds that the sense of absurdity comes from "the cleavage between man's aspirations to unity and the insurmountable dualism of mind and nature, between man's drive toward the eternal and the finite character of his existence, between the 'concern' which constitutes his very essence and the vanity of his efforts".(Sartre,1943,Gale) Absurdity originates from the gap between man's aspirations and the reality, between his longing for eternity and limitedness of the existence, between his thought of essence and his futile efforts. According to Sartre, "Chance, death, the irreducible pluralism of life and of truth, the unintelligibility of the real —all these are extremes of the absurd". (Sartre, 1943, Gale) The absurdity of the world is revealed through chances in life, death, the esoteric reality, uncontrollable forces, etc.

In the novel, the characters live in the woodland-Little Hintock which is closely related to their life. With all manners of people living in it, the Little Hintock can be regarded as an epitome of the world. "The spot is lonely". (Hardy, 2005:1) "The physiognomy of a deserted highway expresses solitude to a degree that is not reached by mere dales or downs, and bespeaks a tomb-like stillness more emphatic than that of glades and pools". (Hardy, 2005:1) "To step...from the edge of the plantation into the adjoining pale thorough fare, and pause amid its emptiness for a moment, was to exchange by the act of a single stride the simple absence of human companionship for an incubus of the forlorn". (Hardy, 2005:1) In Hardy's description, the Little Hintock is a mysterious, forlorn, alien and bleak place covered by trees. In this novel, the Little Hintock is not only the setting for action but also takes part in this story and functions as the determining force. Under the control of the mysterious cosmic power, every creature starts a survival struggle in the Little Hintock. "In this constant, and fierce, reiteration of wounds and sorrow and disease, Hardy establishes the completely unsentimental world in which his characters exist". (Matchett, 1955:258) Man is just a small figure in the total unending struggle in this vast universe which is full of uncontrollable contingencies. The absurdity of the Little Hintock is presented through the gap between the characters' desires for order and rationality and the hostility of the reality. As a small figure in this uncompassionate universe, every character lives at the mercy of it and is haunted by the sense of absurdity. The protagonist, Giles Winterborne is such a small figure living in this absurd world.

Winterborne harbors a love for nature and he can understand the language of nature and natural cycle. Even his name, "Winterborne" can be split into two words: winter + borne, which means "born in winter" and indicates his close 
relationship with nature. He is called "the brother of autumn" by Grace Melbury. However, "the brother of autumn" is thrown into queer situations which are beyond his control.

In the absurd Little Hintock, Winterborne's house leasehold is dependent upon the life of John South, a kinsman of Winterborne. In the novel, South's life has been "used as a measuring-tape of time by law". (Hardy, 2005:82) At the end of his life, both his and Winterborne's houses, "would fall in and become part of the encompassing estate". (Hardy, 2005:82) It sounds ridiculous that human life is used as the measure of tenancy duration in the Little Hintock. In fact, the property of these houses has originally belonged to Winterborne's family and he feels absurd that what could have induced his ancestors to exchange their old copyholds for life-leases. Winterborne's forefathers have accepted the claim of the manor of the Hintock House and have forsaken the copyholds of the houses and other rights "in consideration of having the dilapidated houses rebuilt by the said lord". (Hardy, 2005:82) They have signed a bond with the manor of the Hintock House. According to the bond, "when the last of the stated lives should drop", (Hardy, 2005:82) the property of the house will come to the hands of the manor of the Hintock House. John South is the last of the stated lives and his death causes the losing of Winterborne's houses. In the Little Hintock, human life becomes worthy only when it is used as the measure of tenancy and the end of human life declares the end of the leasehold. The worthlessness of human life indicates the absurdity of the world and human beings fall prey to the world. As a small figure in the world, Winterborne is fragile in contradiction with it which is in a mess, with no rationality and leaves him with the sense of absurdity.

From his childhood, Winterborne loves Grace who is a woman of higher education, longing for fashionable clothes and cultivated talking. Considering Winterborne inferior to her education, Grace hesitates about marrying him. The tremendous difference between them makes it impossible for him to realize his dream. Nevertheless, Winterborne still holds his dream insistently. In order to become intimate with Grace, Winterborne holds a Christmas party but it ends in failure because according to Grace, it is rough and coarse. The failure of his Christmas party causes his rudeness which, later, infuriates Mrs. Charmond, the landowner of the Little Hintock, who shows no mercy to demolish his house after his lease with her expires. The loss of his house causes his loss of Grace. As a poor yeoman, Winterborne is thrown into these uncontrollable successive circumstances imposed upon him by the absurd world which usually goes against his wishes and makes him powerless to strike back.

Losing his houses and experiencing failure in love, Winterborne is found by Fitzpiers walking lonely at night "as if he had no object in life". (Hardy, 2005:104) For him, life becomes nothing and meaningless. Absurdity also refers to the indifference of the world when man is in need of consolation. Man's sense of absurdity of the world comes from the confrontation between his call for consolation and the silent irrational world. When man discovers that the world does not take him seriously, the first thought coming into his mind is to shatter it. However, there is no tool for him to destroy it. So it is futile to pray or curse in a world where there is even no way for man to release his resentment. Without praying or cursing, Winterborne accepts his total failure and chooses to pass his life quietly. However, getting much pleasure in playing with Winterborne, the absurd world doesn't wish to stop its games with him. Grace is at a loss when Fitzpiers comes back from his elopement with Mrs. Charmond to seek reconciliation with her. She goes to Winterborne for help. Deeply in love with her, Winterborne gives his shelter to her while he sleeps at a shabby hut. At the night, "the wind began to rise, and after a few prefatory blasts to be accompanied by rain. The wind grew more violent...making branches creak, springing out of the trees upon the chimney, popping its head into the flue; and shrieking and blaspheming at every corner of the walls". (Hardy, 2005:277) "Sometimes a bough from an adjoining tree was swayed so low as to smite the roof in the manner of a gigantic hand smiting the mouth of an adversary, to be followed by a trickle of rain, as blood from the wound. To all this weather Giles must be more or less exposed". (Hardy, 2005:277) Hardy depicts a gothic picture of the destructive power of nature. Although Winterborne always seeks consolation from nature, this time, even nature goes against him. Exposed to great storm and heavy rain, he dies of typhoid. Although he has an affinity with nature, it is nature that takes his life away at the end as a punishment of his love of the civilized Grace.

Amusing itself by playing with Winterborne, the world is not ready to let him off even after his death until Grace chooses to forget him and reconciles with Fitzpiers. From then on, the world stops its sport with him and makes his sacrifice meaningless. Though for many critics, the reconciliation of Grace and Fitzpiers is a failure of the novel, the reconciliation impresses the readers with the sense of absurdity of the world which continues to play a cruel joke on Winterborne even after his death and moreover and it has dramatized the tragic effect of the novel.

\section{AliENATION}

The basic problem of existence faced by man is his alienation. Alienation is "more than isolation or separateness, more than marginal existence which he experiences. Its basic characteristic may best be expressed by the term "estrangement"'. (Bier, 1972: 55) Estrangement is different from isolation or separateness. A man in separation or isolation has not lost his sense of belonging, but a man in alienation or estrangement has no sense of belonging. "Alienation is, in fact, any condition falling short of life's transcendent goal, the achievement of concrete freedom". (Bier, 1972: 86) Alienation happens during the process of man's pursuits of individuality, freedom, dream, etc. in the absurd and indifferent world. Man's haunted sense of alienation arises from the poignant conflicts between man's longing to achieve wholeness and the ruthless world which always thwarts man's longing. Bier holds that "the alienated 
person feels or is made to feel that he is totally other than people in his own group". (Bier, 1972:55) The alienated person loses his belief and feels that he is left alone in this world. With no sense of belonging, he alienates from his social community, natural environment, his own self, etc.

Man's alienation from his fellow men, from the world and from the cosmos is an important point of Hardy's view of existence. In The Woodlanders, Hardy places Winterborne in the absurd Little Hintock and depicts his alienation which is caused by the mysterious, irrational and inescapable contingencies of the world. In the novel, he becomes alienated when his protest against the world comes to nothing. He alienates himself from the social community and its indifferent human relationships which have caused the frustration of his dream. His alienation is a feeling of isolation, homelessness, solitude and being abandoned.

Living in such an absurd and ridiculous world, Winterborne is falling into alienation step by step. Although he dreams of marrying Grace, the harsh reality makes it impossible for him to realize his dream. After the failure of his Christmas party, he is given a cold shoulder by Grace when he is going to cut the tree at South's window. Recognizing her inexorability, he climbs even higher into the sky, "cutting himself off more and more from all intercourse with the sublunary world". (Hardy, 2005:85) "At last he had worked himself so high up the elm, and the mist had so thickened, that he could only just be discovered as a dark grey spot on the light grey zenith". (Hardy, 2005:85) Hurt by Grace's refusal of marriage, Winterborne, for the first time, wishes to escape from the world and is haunted by the sense of alienation. His climbing into the sky and cutting himself off from communication is a kind of alienation from the outside world and its snobbish human relationships. "Both the capacity to suffer and the protest against it show man's alienation from the way of things; this fact of consciousness itself is the ground of human alienation in the cosmos". (Perkins, 1959:257-258) Winterborne suffers a lot in contradiction with the uncontrollable forces of the absurd world and he protests against the world in order to realize his dream, but all his efforts end in failure and come to nothing. His alienation comes from the poignant conflict between his persistent struggle and the frustration of his dream.

His dream is shattered into pieces after he has lost his houses. "From this day of his life onward for a considerable time Winterborne, though not absolutely out of his house as yet, retired into the background of human life and action hereabout".(Hardy, 2005:101) Heart-broken, Winterborne begins to estrange from the normal life in Little Hintock. He moves out to the edge of Little Hintock and lives in a small accommodation in solitude. Frustrated, Winterborne is in a condition of exile and has no sense of belonging. His seclusion indicates his alienation from the normal human life.

Grace's marriage with Fitzpiers accelerates Winterborne's alienation. "During these weeks Giles Winterborne was nowhere to be seen or heard of. At the close of his tenure in Hintock he had sold some of his furniture, packed up the rest - $\mathrm{a}$ few pieces endeared by associations or necessary to his occupation - in the house of a friend neighbour, and gone away". (Hardy, 2005:156) "He was likely to return to Hintock when the cider-making season came round, his apparatus being stored there”. (Hardy, 2005:156) Before Grace's marriage, Winterborne disappears from Little Hintock. His behaviors, such as the selling and packing of his furniture, indicate his seldom return to the Little Hintock except in the cider-making season when he could earn a living. "People said that a certain laxity had crept into his life; that he had never gone near a church latterly, and had been sometimes seen on Sundays with unblacked boots, lying on his elbow under a tree, with a cynical gaze at surrounding objects". (Hardy, 2005:156) He used to be industrious, but now according to narrations of the village people, he becomes sluggish. He does not black his shoes and even never goes to the church on Sundays. That is to say, he has lost his faith in life and in God. Another reason for his never approaching the church is to avoid witnessing the marriage ceremony of the new couple, Grace and Fitzpiers. Disillusioned, Winterborne becomes cynical and he belongs to nowhere. Powerless in this absurd world, he has no other choice but to fall back and alienate from it.

"In a universe suddenly deprived of illusions and of enlightenment, man feels himself a stranger. This exile is without recourse since it is deprived of the memories of a lost homeland [illusion] or the hope of a promised land [illusion]". (qtd. in McGregor, 1997:316) In a world totally deprived of dreams and illusions, Winterborne becomes an outsider of it because there is nothing for him to dream of or rely upon. Lonely in the Little Hintock, Winterborne is helpless and despair. With no belief from which he could find a consolation, he becomes a total stranger to the Little Hintock which is reduced to nothingness. With the disgust of it and loss of belief, he is left alone and there is nothing for him to do in this world, only to sink into the condition of alienation and exile.

\section{BAD FAITH}

As a form of self-deception, bad faith, in Sartre's philosophy, is "the deliberate project of concealing some unpleasant truth from oneself". (Webber, 2002:49) When in bad faith, "an individual denies both the harsh brutality of existence as well as the total gratuity of Being, choosing instead methods of evasion such as abstracted thought or belief in conventional (and often bourgeois) value systems". (Griffin, 2001, Gale) When an individual is in bad faith, he tends to present a displeasing truth as a pleasing untruth. Although he is aware of the harsh reality of the existence, he refuses to face it and deludes himself into believing something is not what it is. Sartre holds that "the difference that separates those with authentic existential perspective from those without it" involves the latter group's performance of bad faith, "by means of which an individual evades his moral responsibility". (Griffin, 2001, Gale) Such evasion, according to Sartre, is immoral. "One must choose to confront one's existence, acknowledging one's past for what it is-mediocre, ineffectual, or whatever-and then choose to throw oneself forward, to project oneself, to be, creating for oneself an 
essence-a history - involving authentic commitment and action rather than continued inauthentic, self-deceived flight". (Griffin, 2001, Gale) An individual must confront the harsh reality and admit his imperfections, such as his mediocrity, powerlessness, deficiencies, and should struggle against the relentless reality in order to pursue the authenticity of his existence. On the contrary, an individual in bad faith falls back to the self-deluding evasion of the relentless reality, and lives inauthentically in this irrational and absurd world.

In The Woodlanders, Hardy reveals Winterborne's bad faith which is responsible for his tragedy. As a poor yeoman, he can hardly satisfy Grace's desires for fashion and culture. Although sometimes he has been aware of the tremendous difference between them and is doubt of their marriage, he chooses to ignore the relentless reality and nourishes a deep love for her. He has been deceiving himself and acting in bad faith by refusing to face the brutal reality. Persisting in his bad faith, he keeps daydreaming and lives inauthentically in this absurd world.

After the failure of his Christmas party, he should have recognized the true circumstance clearly. Winterborne, "who might better blame his foolish desire to adopt the 'higher' social standards he imputes to Grace" (Steig, 1971:107) feels that "the fates were against him". (Hardy, 2005:67) Winterborne ignores his own limitations and casts the blame on fates. He keeps evading the reality and disregarding his potentiality and holds his bad faith, believing in something that is not what it is. When he is cutting the tree outside South's window, still cherishing the hope of making up for his relationship with Grace after the Christmas party, he begs Grace to speak to him, only to be given a cold shoulder by her. Even after the loss of his houses, Winterbonre still cherishes his illusion and takes part in the Midsummer Eve ritual which is a ritual for the girls to find their future partners, because he wishes to become Grace's fated husband. Again, he fails and Fitzpiers wins Grace. Of course, he is deeply aware of the cruel reality that he shall never marry Grace, but he works hard to delude himself by refusing to confront it. His bad faith makes him cherish his daydream and brings him much agony each time after the failure of his action.

After Grace's marriage with Fitzpiers, he should have abandoned his love for her and striven for his own happiness. However, he is still obsessed with her and refuses to face the reality. When Grace's marriage comes to a crisis because of Fitzpiers's affair with Mrs. Charmond, Winterborne chooses to court Grace, though he is not sure whether Grace will really get a divorce. "Indeed he cared for nothing past or future, simply accepting the present and what it brought". (Hardy, 2005:262) His bad faith brings desperation to him after failure of Grace's divorce. At that time, he still performs self-deception by trying to kiss her although "he perfectly well knew her to be wedded irrevocably to Fitzpiers". (Hardy, 2005:262) Winterborne deludes himself again and tries to ignore Grace's married status. The true reality is that it is impossible for him to win the married Grace who has been accustomed to be wife of a cultivated professional man such as Fitzpiers. Winterborne's bad faith has inspired him with hope at first but has pushed him into to the abyss of ruin at last.

Fitzpiers's return from his elopement to seek reconciliation with Grace makes her turn to Winterborne for help to leave the Little Hintock. Sinking into his bad faith, Winterborne begs her to stay, gives his accommodation to her and sleeps at a shabby shade outside. Seeing the destructive powers of the great storm and heavy rain, Grace asks him to sleep inside with her. However, holding his bad faith of the bourgeois moral conventionality and taking no consideration of his former sickness, Winterborne refuses her request and sleeps outside. Winterborne dies of typhoid because of his exposure to the storm and rain. Obsessed with Grace, Winterborne does what he can do to help her, disregarding his own potentiality. In all his life, he lives in bad faith, persists in conventional morality, takes no consideration of his personal potentiality and refuses to confront the reality. His persistence of bad faith prevents himself from pursuing his authentic living and causes his tragic death. Grace's reconciliation with Fitzpiers is a declaration of the failure of Winterborne's bad faith and an irony to it.

\section{CONCLUSION}

The Woodlanders is a tragedy of existence. The Little Hintock described by Hardy, is absurd and is reduced to nothingness. The protagonist, Giles Winterborne is cast into such an absurd and irrational world, alienates from it and loses his sense of belonging. He holds his bad faith which plays a significant role in his tragic death. The absurd world, Winterborne's alienation and his bad faith are responsible for his tragedy. Through Giles Winterborne, Hardy explores the predicament of existence of people living at the turn of the $20^{\text {th }}$ century. Although Hardy is a writer of the later Victorian period, his pondering over the human existence is still thought-provoking today.

\section{REFERENCES}

[1] Bier, William Christian. (1972). Alienation: Plight of Modern Man? New York: Fordham University Press

[2] Griffin, Christopher O. (2001). Bad faith and the ethic of existential action: Kierkegaard, Sartre, and a boy named Harry. http://go.galegroup.com/ps/i.do?\&id=GALE\%7CA80163239\&v=2.1\&u=cncqu\&it=r\&p=LitRG\&sw=w (accessed 17/4/2010).

[3] Hardy, Thomas. (2005). The Woodlanders (Oxford World's Classics). Oxford: Oxford University Press.

[4] Matchett, William H. (1955). The Woodlanders or realism in sheep's clothing. Nineteenth-Century Fiction 9.4, 241-261.

[5] McGregor, Rob Roy. (1997). Camus's The Silent Men and the Guest: depictions of absurd awareness. Studies in Short Fiction 34.3, 307-320.

[6] Perkins, David. (1959). Hardy and the poetry of isolation. ELH 26.2, 253-270.

[7] Sartre, Jean-Paul. (1943). Camus's The Outsider (Trans. Michelson, Annette). (accessed 17/4/2010). 
http://go.galegroup.com/ps/i.do?\&id=GALE\%7CH1100000158\&v=2.1\&u=cncqu\&it=r\&p=LitRG\&sw=w

[8] Steig, Michael. (1971). Art versus philosophy in Hardy: "The Woodlanders". Mosaic 4.3, 103-110.

[9] Webber, Jonathan. (2002). Motivated aversion: non-thetic awareness in bad faith. Sartre Studies International 8.1, 45-99.

Yanjuan Chen was born in Henan, China in 1985. She is studying for her MA's degree in the College of Foreign Languages of Chongqing University. Her research interests include the literature of English language and Western literary theories. 